\title{
MANFAAT PEMASANGAN OPTICAL TERMINATION PREMISES DALAM JARINGAN FIBER TO THE HOME
}

\section{BENEFIT OF OPTICAL TERMINATION PREMISES IN THE FIBER TO THE HOME NETWORK}

\author{
Mahyar Koswara \\ Reseacher M2M and Fixed Broadband Access, \\ Telkom Divisi Digital Service \\ 1mahyar@telkom.co.id
}

\begin{abstract}
Abstrak
Tumbuhnya pelanggan broadband berbasis jaringan Fiber To The Home (FTTH) ternyata dibarengi dengan banyaknya keluhan atau gangguan yang terjadi. Keluhan yang terjadi adalah lamanya waktu penyelesaian atau perbaikan gangguan dan sulitnya Teknisi masuk ke dalam rumah pelanggan saat melakukan perbaikan gangguan. Gangguan terbesar berada pada segmen antara Optical Distribution Point (ODP) dan Roset [1]. Gangguan yang terjadi pada segmen ini adalah sering terjadi putusnya kabel drop. Pada umumnya aktivitas yang dilakukan jika ada gangguan/putus kabel drop, baik itu di bagian outdoor maupun indoor proses perbaikannya kabel drop diganti mulai dari ODP sampai ke Roset. Hal ini tidak terlepas dari desain infrastruktur jaringan pelanggan FTTH [2]. Dalam desain jaringan pelanggan FTTH ini kabel drop ditarik dari port output adapter ODP yang berada di luar rumah sampai ke Roset yang berada di dalam rumah. Berdasarkan standar instalasi [3] [4] bahwa instalasi kabel drop dari ODP ke Roset harus melalui perangkat OTP. Pemasangan OTP bertujuan untuk mempermudah melokalisir gangguan dan demarkasi atau titik batas antara kabel bagian luar rumah (outdoor) dan bagian dalam rumah (indoor). Dengan dipasangnya ODP jika terjadi gangguan maka kabel yang terganggu itu saja yang dilakukan perbaikan atau penggatian dan hal ini akan menghemat/efesien dalam pemakaian kabel drop.
\end{abstract}

\section{Kata kunci: OTP, FTTH, Broadband}

\begin{abstract}
The growth of broadband subscriber network based on Fiber-To-The-Home (FTTH) turned out to be coupled with the large number of complaints or disturbance. Complaints are often is the length of time the completion of repair or interference and Engineers is difficult into the house when doing repair disorders. The biggest distractions that are in the segment between Optical Distribution Point (ODP) and rosette [1]. Disturbance in this segment are often drop cable cuts. The activities undertaken if there is an interruption or end drop wires, either at the indoor and outdoor drop cable repair process changed from ODP to the rosette. It is not independent of the network infrastructure design FTTH subscribers [2]. In the design of the customer's network is FTTH drop cable is pulled from the output port adapter ODP that is outside the house to the rosette that was in the house. Based on the standard installation [3] [4] stated that the installation of cables drop from ODP to rosette through the device OTP. Installation of OTP aims to simplify locating interference and a demarcation or boundary point between the cable outside of the house (outdoor) and the inside of the house (indoor). Thus, if there is interference on outdoor or indoor wiring
\end{abstract}


cables interrupted only then was it conducted repairs or replacement and it will save or efficient in the use of drop cable.

\section{Keywords: OTP, FTTH, Broadband}

\section{PENDAHULUAN}

FTTH atau Fiber To The Home merupakan teknologi jaringan akses yang medianya menggunakan kabel fiber optik mulai dari perangkat aktif sampai dengan pelanggan (last mile). Teknologi FTTH ini mempunyai beberapa keunggulan jika dibandingkan dengan teknologi jaringan yang masih menggunakan kabel tembaga atau teknologi wireless. Salah satu keunggulan dari teknologi FTTH ini adalah kemampuan menyalurkan sinyal sampai dengan 100 Mbps yang stabil dan mampu melayani pelanggan sampai radius kurang lebih 20 kilo meter. Saat ini beberapa Operator Telekomunikasi besar seperti PT. Telekomunikasi Indonesia (Telkom), First Media, PT. Excelcomindo (Exel), MNC Media dan PT. Supra Primatama Nusantara (Biznet) dalam melayani pelanggannya menggunakan teknologi ini, dengan memiliki desain maupun cara instalasi jaringan pelanggan masing-masing. Dengan semakin banyak operator telekomunikasi yang melayani pelanggannya menggunakan jaringan kabel fiber optik, maka semakin banyaknya/tumbuhnya pelanggan FTTH. Tumbuhnya jumlah pelanggan Fixed Broadband berbasis teknologi Fiber To The Home (FTTH) berdampak positif baik untuk pelanggan, operator penyelenggara jaringan FTTH maupun pemerintah. Dengan menggunakan jaringan FTTH, pelanggan akan mendapatkan bandwidth yang lebih besar sehingga akan semakin mudah dalam memenuhi kebutuhan apapun, apakah untuk kebutuhan bisnis ataupun pribadi. Untuk operator jasa penyedia jaringan FTTH akan menambah kepercayaan dari pelanggan dan pendapatan keuangan sedangkan bagi pemerintah akan meningkatkan roda perekonomian. Disamping dampak positif yang terjadi, terdapat juga dampak negatifnya yaitu banyaknya keluhan/gangguan pelanggan FTTH tersebut. Keluhan yang banyak disampaikan/diadukan oleh para pelanggan adalah lamanya waktu perbaikan atau penyelesaian gangguan. Keluhan yang timbul tidak hanya dari Pelanggan, Teknisi yang akan memperbaiki gangguanpun ternyata sering mengeluh yaitu tidak dapat masuk ke dalam rumah pelanggan saat akan melakukan trouble shooting. Teknisi hanya diperbolehkan masuk sampai ke area luar (teras) rumah pelanggan tersebut. Dari hasil survey dan pengamatan terhadap konfigurasi jaringan FTTH dilapangan dan interview dengan Teknisi yang menangani perbaikan gangguan, ternyata gangguan tersebut banyak disebabkan putusnya kabel drop antara bagian luar rumah dan ODP. Kerusakan/putus kabel drop dapat terjadi hanya di bagian luar rumah atau bagian dalam rumah saja, tetapi dalam perbaikannya kabel drop tetap diganti mulai dari ODP sampai Roset dalam rumah. Hal ini tidak terlepas dari model desain konfigurasi dan implementasi secara umum untuk instalasi jaringan pelanggan berbasis fiber optik (FTTH) tersebut.

Tujuan penulisan jurnal ini untuk memberikan solusi dalam percepatan penyelesaian gangguan dan penghematan atau efesiensi dalam penggunaan material kabel drop.

Metodologi dalam penulisan jurnal ini di lakukan dengan pengumpulan data melalui site survey dan interview ke salah satu operator telekomunikasi (PT. Telkom) dan melakukan on desk study baik melalui searching internet atau mempelajari dokumen eksisting terkait desain konfigurasi dan instalasi jaringan pelanggan FTTH. Kemudian data-data tersebut di analisa apakah terjadi gap antara teori atau standar yang ada dengan kondisi eksisting dan Oportunity For Improvement (OFI) yang bisa dilakukan sehingga menghasilkan suatu kesimpulan serta saran untuk perbaikan lebih lanjut. 


\section{DASAR TEORI}

Berdasarkan standar ITU - T G.984.2 topologi jaringan Fiber To The x (FTTx) adalah seperti gambar berikut ini.

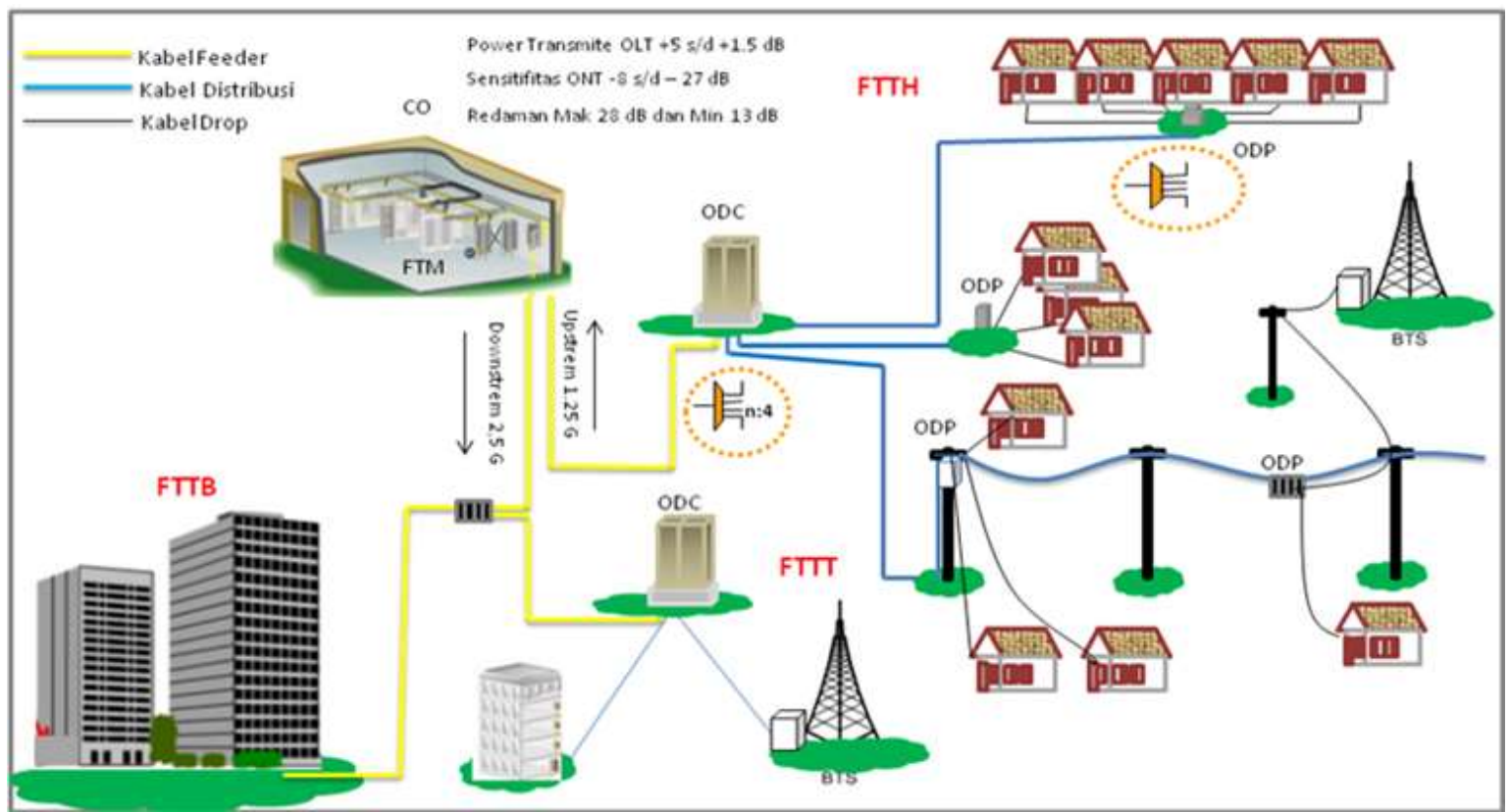

Gambar 13. Topologi FTTx (ITU -T G.984.2)

Ruang lingkup jaringan fiber optik pada teknologi FTTx mulai dari perangkat ODF/FTM sampai dengan Roset yang berada dilokasi pelanggan. Adapun modus aplikasi dari teknologi FTTx ini di implementasikan untuk layanan Backhaul/Mobile/Node-B, High End Market seperti Gedung bertingkat (HRB), Kawasan Bisnis dan Pelanggan Residensial. Modus aplikasi dari Jaringan Fiber To The X (FTTx) seperti gambar berikut ini.

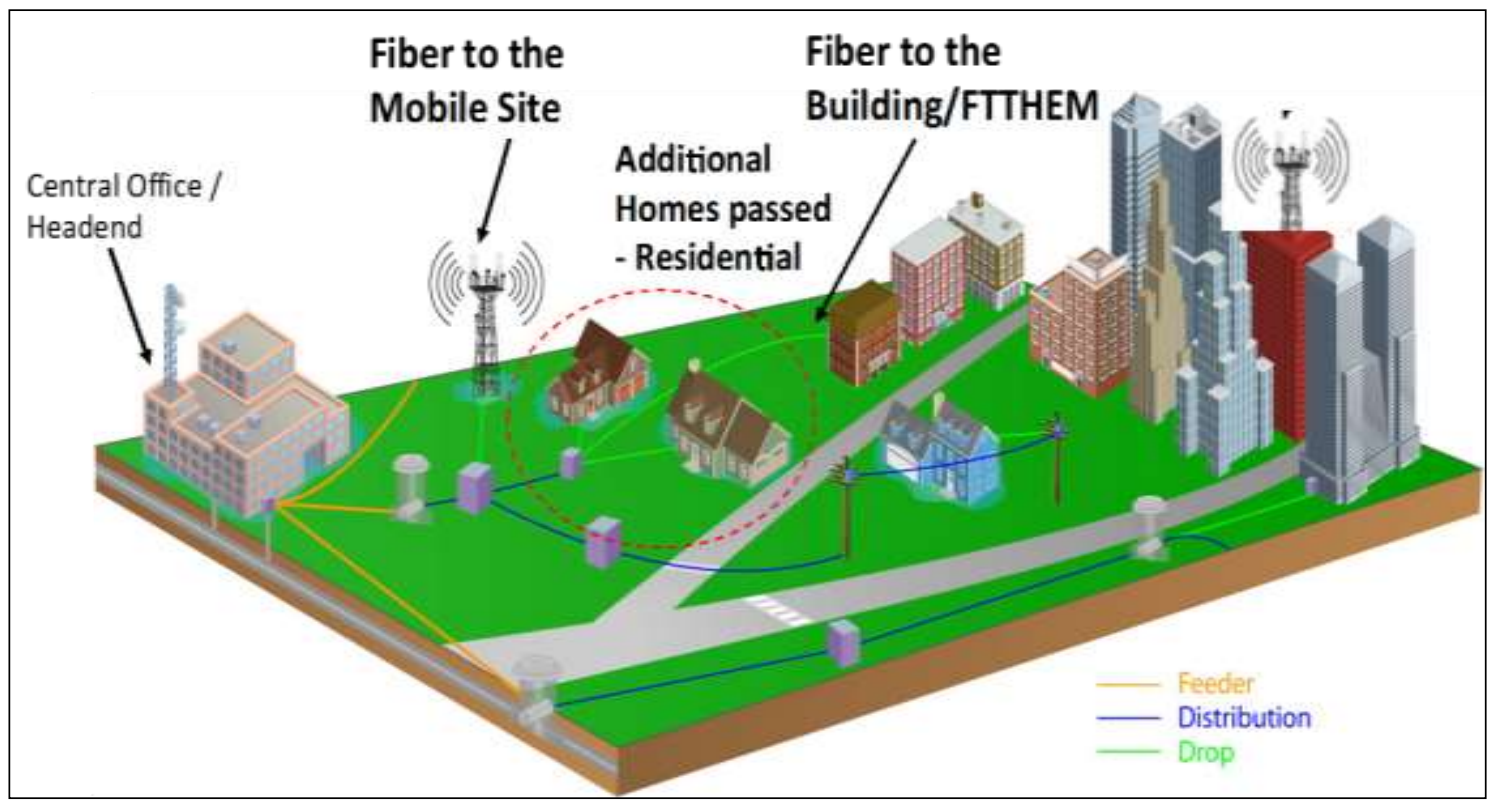

Gambar 14. Modus Aplikasi Jaringan FTTx 
Konfigurasi dasar jaringan akses fiber FTTx sama hal seperti pada jaringan akses tembaga dimana terdapat segmen-segmen catuan. Pada Jaringan akses fiber FTTx terdapat catuan kabel Feeder, catuan kabel distribusi, catuan kabel drop dan catuan kabel indoor serta perangkat aktif OLT dan ONU/ONT.

Salah satu implementasi dari teknologi jaringan FTTx ini adalah untuk melayani pelanggan residensial atau yang lebih kita kenal jaringan pelanggan Fiber To The Home atau FTTH. Desain konfigurasi jaringan FTTH dari salah satu Operator penyedia infrastruktur ini adalah sebagai berikut:

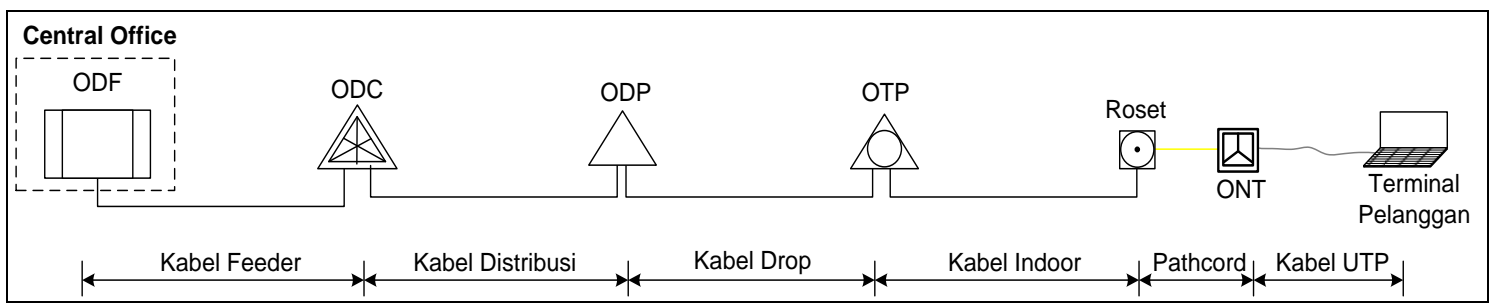

Gambar 15. Konfigurasi Jaringan FTTH

Dari konfigurasi ini terlihat sistim jaringan untuk pelanggan FTTH dibagi menjadi beberapa segmen yaitu:

a. Segmen Feeder, yaitu catuan kabel antara perangkat ODF dan ODC

b. Segmen Distribusi, yaitu catuan kabel antara perangkat ODC dan ODP.

c. Segmen Drop, yaitu catuan kabel antara ODP dan OTP

d. Segmen Indoor, yaitu catuan kabel antara OTP dan Roset.

Adapun Infratsruktur atau material yang terdapat pada masing-masing segmen dapat terlihat pada Tabel berikut ini.

Tabel 1. Data Material Masing-masing Segmen

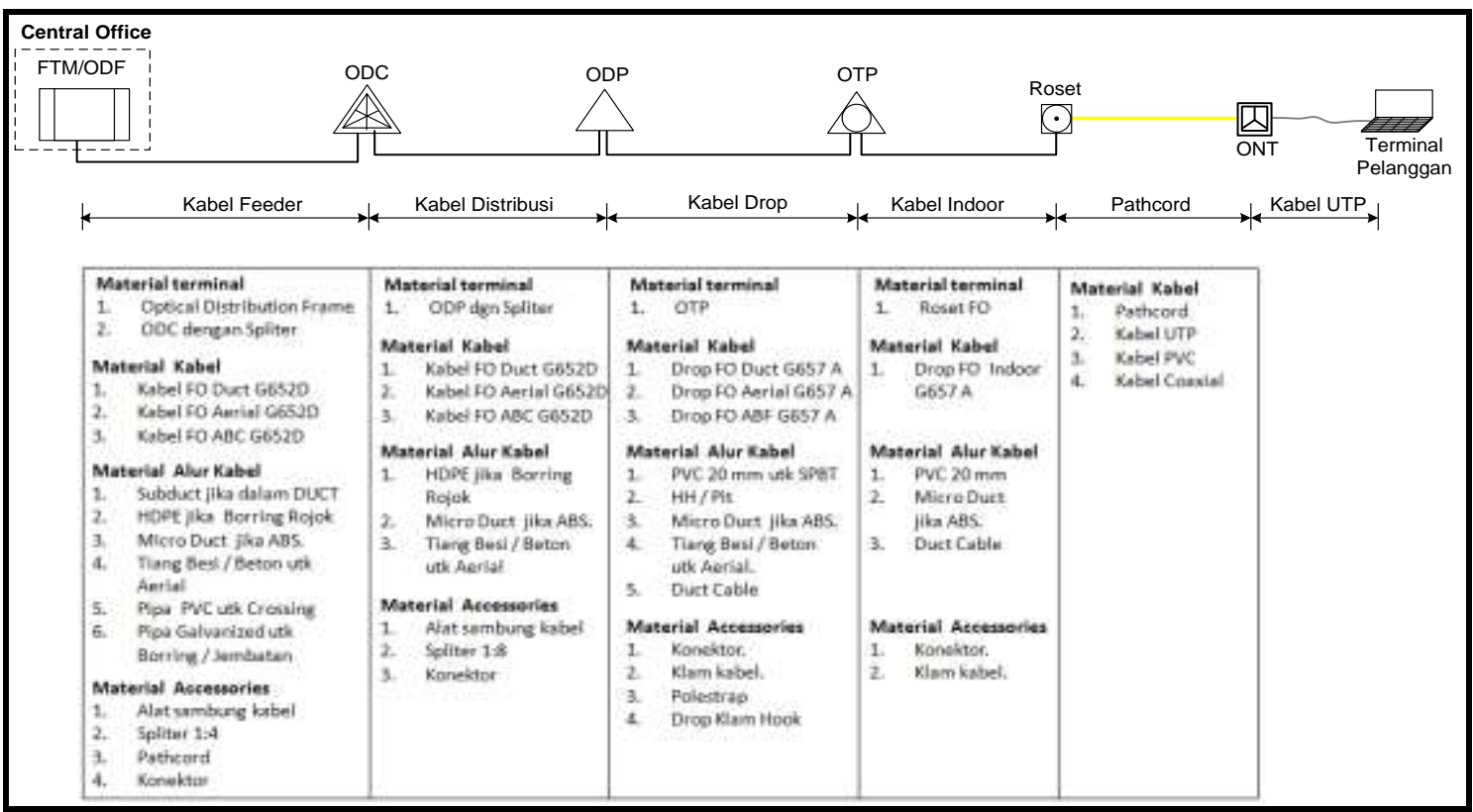




\section{METODOLOGI}

Metodologi yang dipergunakan merupakan metode penelitian kualitatif yang melakukan analisa terhadap data-data yang terkumpul, yang kemudian menghasilkan suatu kesimpulan dan saran yang bermanfaat untuk proses perbaikan ke depan. Data-data yang dikumpulkan berasal dari beberapa operator telekomunikasi yang memiliki infrastruktur layanan ini seperti PT. Telkom, MNC Media dan First Media. Proses pengumpulan data dilakukan dengan cara melakukan site survey untuk melihat konfigurasi eksisting pelanggan dan melalui on desk study. Dari semua data tersebut akan dilakukan analisa mana yang sudah baik dan mana yang perlu dilakukan perbaikan yang akan membuat proses penanganan gangguan menjadi cepat dan efektif. Sesuatu hal baru yang tidak ada dalam proses sebelumnya akan dijadikan saran yang sebaiknya diterapkan/dilaksanakan untuk proses selanjutnya. Secara global metode penelitian ini dapat terlihat pada blok diagram berikut ini.

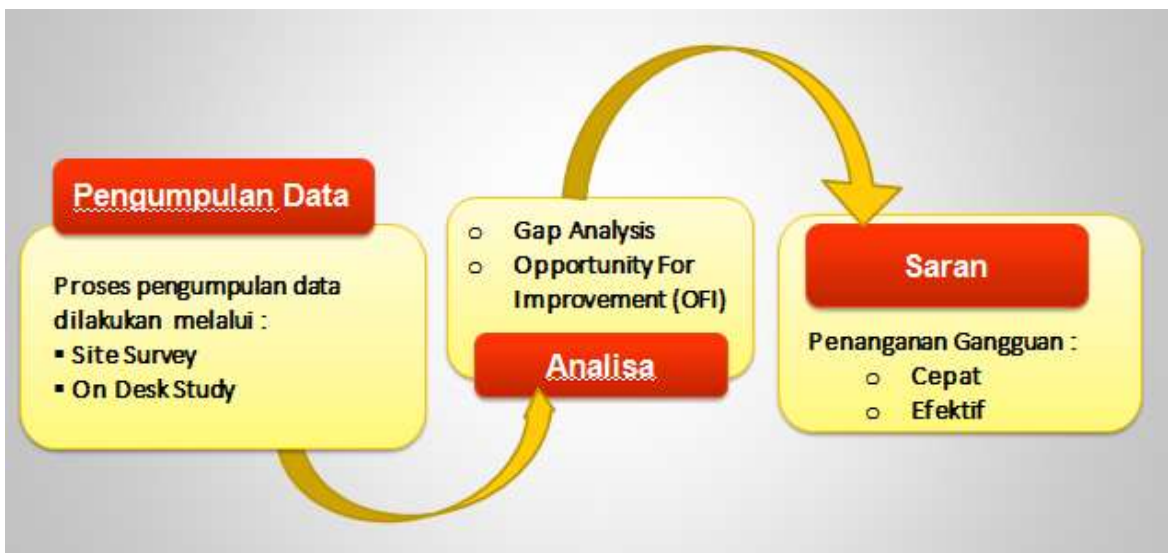

Gambar 4. Diagram Metode Penelitian

\subsection{Kegiatan Site Survey}

Untuk memudahkan dalam melakukan kegiatan site survey terlebih dahulu dibuat tabel parameter apa saja yang menjadi obyek pengamatan. Berdasarkan laporan hasil kegiatan uji petik terhadap implementasi jaringan akses untuk pelanggan FTTH tahun 2015 yang dilakukan oleh PT. Telkom 4[1], parameter yang berpengaruh terhadap potensi gangguan adalah instalasi ODP, Kabel Drop, OTP dan Roset. Adapun parameter lainnya merupakan parameter yang berpengaruh terhadap nilai estetika dan kemudahan dalam melakukan operasional dan maintenance (O\&M). Model tabel yang dijadikan acuan dalam pelaksanaan site survey seperti Tabel 2 berikut ini.

Tabel 2. Model Tabel untuk keperluan Site Survey

\begin{tabular}{|c|c|c|c|c|}
\hline No. & $\begin{array}{l}\text { KONDISI \& MATERIAL } \\
\text { INSTALASI }\end{array}$ & OK & NOK & KETERANGAN \\
\hline 1 & ODP & & & \\
\hline 2 & Kabet Drop & & & \\
\hline 3 & Terpasang Bracket/segitiga & & & \\
\hline 4 & $\begin{array}{l}\text { Menggunakan stopper di } \\
\text { kabel drop }\end{array}$ & & & \\
\hline 5 & Menggunakan OTP & & & \\
\hline 6 & $\begin{array}{l}\text { Kabel Drop masuk ke dalam } \\
\text { rumah }\end{array}$ & & & \\
\hline 7 & Menggunakan kabel Indoor & & & \\
\hline 8 & Terpasang Roset & & & \\
\hline 9 & $\begin{array}{l}\text { instalasi dalam rumah } \\
\text { mengguna-kan kabel tray }\end{array}$ & & & \\
\hline 10 & $\begin{array}{l}\text { Kabel pacthcord yang } \\
\text { digunakan SC/UPC-SC/UPC }\end{array}$ & & & \\
\hline
\end{tabular}


Dalam kegiatan site survey ini dilakukan juga interview kepada petugas teknis yang menangani perangkat aktif untuk layanan pelanggan FTTH (bagian logic) dan kepada petugas teknis lapangan yang mengerjakan bagian pisik pasang baru dan yang memperbaiki gangguan pelanggan.

\subsection{Kegiatan On Desk Study}

Kegiatan yang dilakukan dalan on desk study ini adalah sebagai berikut:

a. Mempelajari dokumen laporan hasil uji petik terhadap implementasi jaringan pelanggan FTTH Telkom tahun 2015 [1].

b. Melakukan searching melalui internet tentang konfigurasi jaringan pelanggan FTTH untuk operator telekomunikasi MNC Media dan First Media [5] .

c. Mempelajari dokumen hasil joint experience antara Telkom Akses dan Fujikura, Ltd. tentang prosedure instalasi jaringan FTTH [6].

\section{PEMBAHASAN}

\subsection{Hasil Pengumpulan dan Analisa Data Site Survey}

Kegiatan site survey ini dilakukan terhadap pelanggan FTTH eksiting, pengamatan terhadap proses instalasi pasang baru (PSB) dan proses penanganan/perbaikan gangguan. Sampel lokasi site survey ini dilakukan terhadap pelanggan PT. Telkom di wilayah pelayanan Bekasi, Bandung dan Surabaya. Adapun jumlah sampel site survey sebagai berikut:

a. Wilayah Pelayan Telkom Bekasi sebanyak 19 pelanggan, meliputi :

1) Area Layanan Cibitung 4 pelanggan

2) Area Layanan Kranji 5 pelanggan

3) Area Layanan Juanda 5 pelanggan

4) Apartemen Grand Center Point 5 pelanggan

b. Wilayah Pelayan Telkom Bandung sebanyak 30 pelanggan, meliputi :

1) Area Layanan Gegerkalong 20 pelanggan

2) Area Layanan Banjaran 10 pelanggan

c. Witel Pelayanan Telkom Surabaya sebanyak 20 pelanggan, meliputi :

1) Area Layanan Injiko 15 pelanggan

2) Area Layanan Waru 5 pelanggan

Dari hasil site survey yang telah dilakukan di peroleh data seperti pada Tabel 3 berikut ini.

Tabel 3. Data Hasil Site Survey

HASIL DATAPENGAMATAN INSTALASI PELANGGAN FTTH
Jumlah sampel data sebanyak 69 Pelanggan
\begin{tabular}{|c|l|c|c|c|}
\hline No. & \multicolumn{1}{|c|}{$\begin{array}{c}\text { KONDISI \& MATERIAL } \\
\text { INSTALASI }\end{array}$} & OK & NOK & KETERANGAN \\
\hline 1 & ODP & 50 & 19 & \\
\hline 2 & Kabel Drop & 49 & 20 & \\
\hline 3 & Terpasang Bracket/segitiga & 51 & 18 & \\
\hline 4 & $\begin{array}{l}\text { Menggunakan stopper di kabel } \\
\text { drop }\end{array}$ & 19 & 50 & \\
\hline 5 & Menggunakan OTP & 19 & 50 & 50 tidak dipasang OTP \\
\hline 6 & $\begin{array}{l}\text { Kabel Drop masuk ke dalam } \\
\text { rumah }\end{array}$ & 69 & 0 & \\
\hline 7 & \begin{tabular}{l} 
Menggunakan kabel Indoor \\
\hline 8
\end{tabular} & 0 & 69 & $\begin{array}{l}69 \text { tidak menggunakan } \\
\text { Terpabel indoor }\end{array}$ \\
\hline 9 & $\begin{array}{l}\text { Instalasi dalam rumah } \\
\text { menggunakan kabel tray }\end{array}$ & 30 & 39 & \\
\hline 10 & $\begin{array}{l}\text { Kabel pacthcord yang } \\
\text { digunakan SC/UPC-SC/UPC }\end{array}$ & 49 & 20 & \\
\hline
\end{tabular}


Sesuai dengan parameter yang telah ditentukan pada saat akan melakukan pengumpulan data, yaitu melakukan pengamatan terhadap parameter penting yang berpengaruh terhadap potensi terjadinya gangguan, yaitu instalasi ODP, Kabel Drop, OTP dan Roset maka data yang diperoleh dari 69 sampel pengamatan pelanggan adalah sebagai berikut:

a. Instalasi ODP yang tidak memenuhi spek teknis sebanyak 19 pelanggan

b. Instalasi Kabel Drop yang tidak memenuhi spek teknis sebanyak 30 pelanggan

c. Instalasi pelanggan yang tidak terpasang OTP sebanyak 50 pelanggan

d. Instalasi pelanggan yang tidak menggunakan Roset sebanyak 23 pelanggan

Dari data site survey yang diperoleh terdapat data yang cukup menarik untuk dibahas lebih jauh yaitu terkait dengan instalasi/pemasangan perangkat OTP. Dari 69 sampel pelanggan yang di amati hanya 19 pelanggan yang terpasang OTP sedangkan 50 pelanggan tidak terpasang. Berdasarkan desain konfigurasi jaringan FTTH dari salah satu Operator Telekomunikasi, OTP merupakan salah satu bagian penting dari konfigurasi jaringan FTTH [2].

Hasil interview dan penelusuran lebih jauh, penyebab instalasi tidak menggunakan OTP salah satu alasannya karena dengan melakukan penambahan OTP akan menambah redaman dan biaya. Tidak dipungkiri dengan adanya pemasangan perangkat OTP akan menambah redaman sebesar maksimal 1 (satu) dB dan biaya investasi, tetapi jika dibandingkan dengan aspek manfaatmya keberadaan OTP ini akan lebih penting dari pada isu/alasan adanya penambahan redaman dan biaya investasi. Hasil data site survey dilapangan pemasangan perangkat OTP hanya menambah redaman 0,7 dB. Dari hasil pengukuran salah satu pelanggan dilapangan yang menggunakan/terpasang OTP terlihat sebagai berikut ini. Besar power budget di port adapter ujung kabel drop sebelum masuk ke input port OTP nilainya $-20,75 \mathrm{dBm}$. Setelah dimasukan ke output OTP, besar power bubget di output OTP nilainya $-21,45 \mathrm{dBm}$. Dengan demikian besar redamannya $-20,75 \mathrm{dBm}-(-21,45 \mathrm{dBm})$, sehingga besar redaman OTP 0,7 dB.
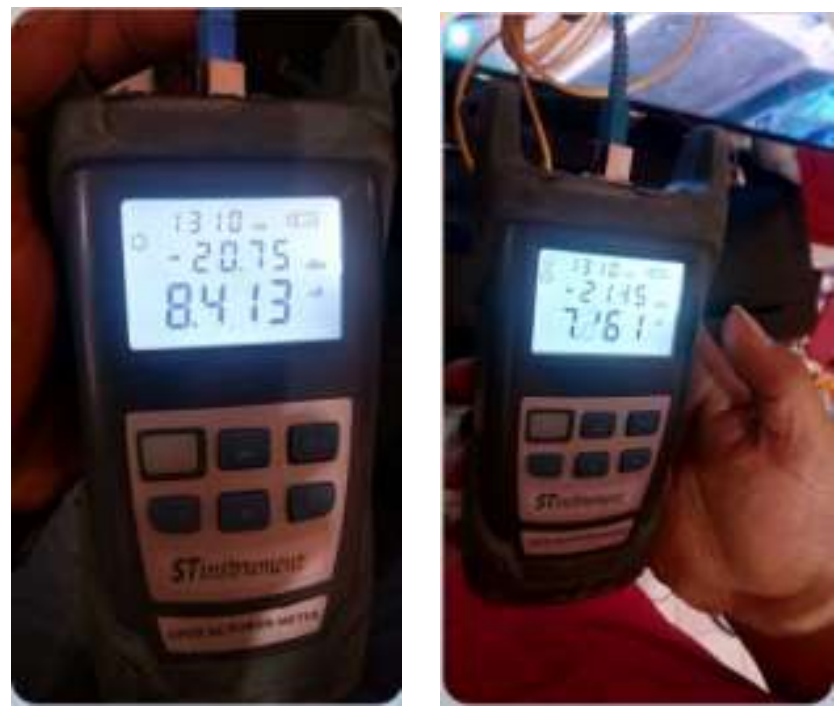

Gambar 5. Hasil Pengukuran Power Bubget di Bagian Input dan Output OTP

\subsection{Hasil Pengumpulan dan Analisa Data Om Desk Study}

Dari hasil on desk study melalui searching internet, metode atau cara instalasi Operator Telekomunikasi dari MNC Media dan First Media [5] terlihat pada gambar berikut ini. 


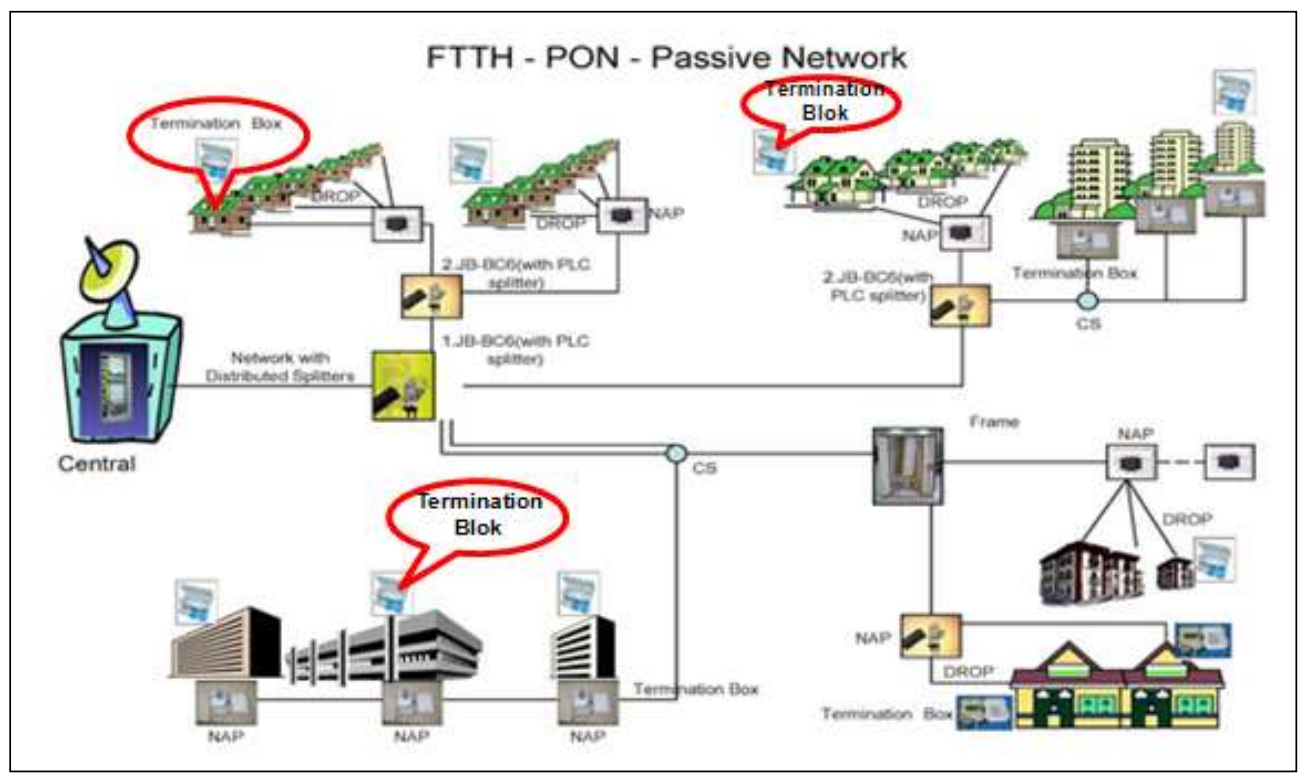

Gambar 6. Konfigurasi 1 Jaringan Pelanggan FTTH MNC Media

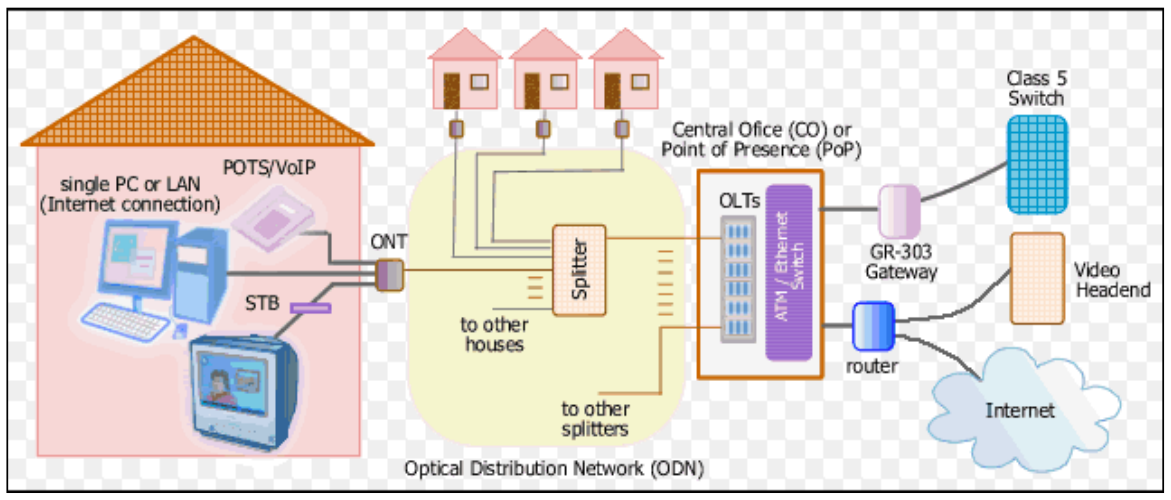

Gambar 7. Konfigurasi 2 Jaringan Pelanggan FTTH MNC Media

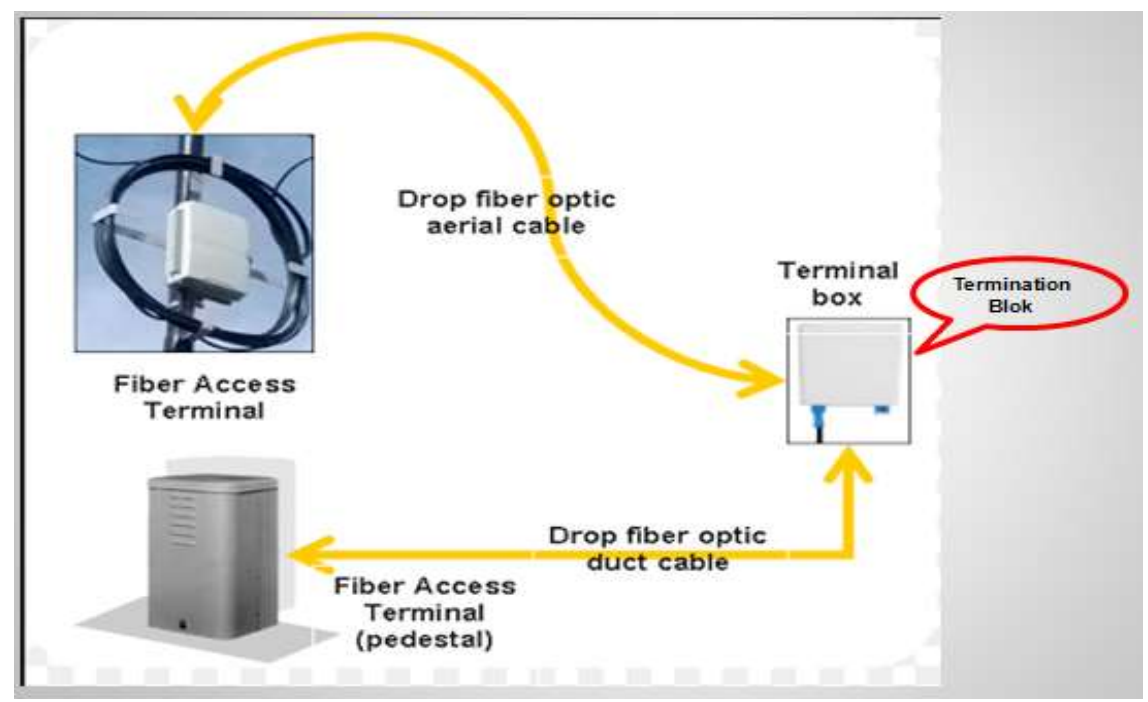

Gambar 8. Konfigurasi Jaringan Pelanggan FTTH Fisrt Media 
Dari data yang di dapat konfigurasi infrastruktur jaringan pelanggan FTTH MNC Media dan First Media [5] tidak terpasang/menggunakan perangkat OTP. Terlihat dari gambar di atas kabel drop ditarik langsung dari ODP sampai Roset (Terminal Blok) yang berada dalam rumah. Seperti telah dijelaskan sebelumnya bahwa desain konfigurasi ini tidak efektif karena dalam proses perbaikan/penanganan gangguan waktunya akan lama dan berpotensi menimbulkan pemborosan kabel drop.

Adapun konfigurasi jaringan FTTH berdasarkan dokumen hasil joint experience antara Telkom Akses dengan Fujikura, Ltd.[6] adalah sebagai berikut.

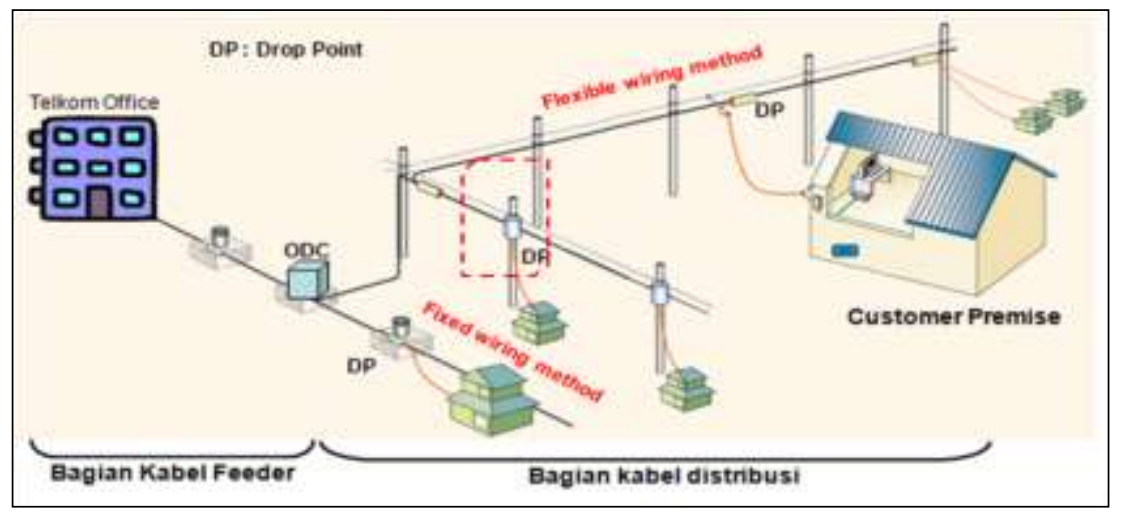

Gambar 9. Konfigurasi Implementasi Jaringan Pelanggan FTTH Hasil Joint Experince Antara Telkom Akses dan Fujikura
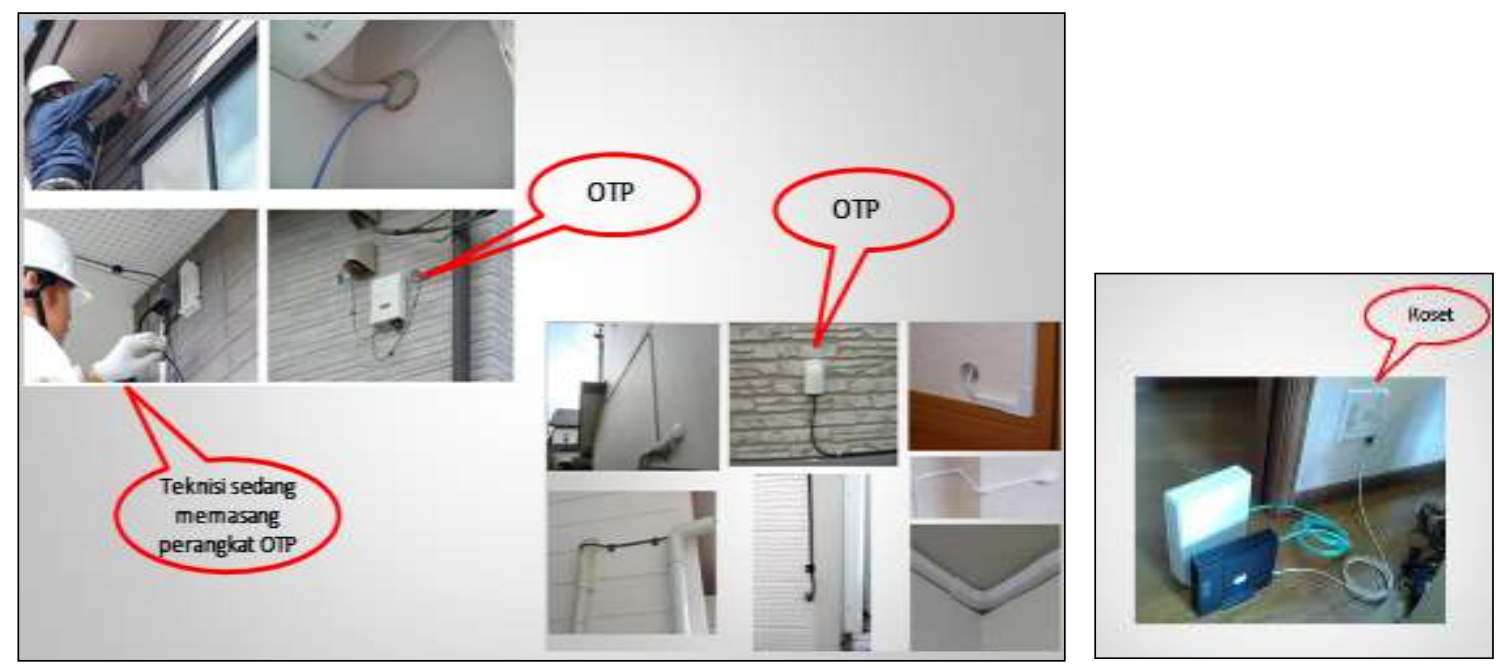

Gambar 10. Pemasangan OTP pada Jaringan Pelanggan FTTH Hasil Joint Experince Antara Telkom Akses dan Fujikura

Dari data dokumen joint experience antara Telkom Akses dan Fujikura [6] di dapatkan data bahwa konfigurasi infrastruktur jaringan pelanggan pelanggan FTTH terpasang/menggunakan perangkat OTP. Terlihat dari gambar di atas kabel drop ditarik/diterminasi ke OTP dulu, kemudian dari OTP ditarik kabel indoor ke Roset yang berada dalam rumah.

Konfigurasi jaringan pelanggan FTTH seperti ini yang disarankan diimplementasikan karena akan mempercepatan dalam proses perbaikan/penanganan gangguan di segmen kabel drop dan akan menghemat pemakaian kabel drop. 


\subsection{Cara Instalasi Perangkat OTP}

Berikut ini adalah contoh phisik dan cara instalasi perangkat OTP dalam sistim jaringan pelanggan FTTH yang menggunakan kabel drop aerial (kabel udara).

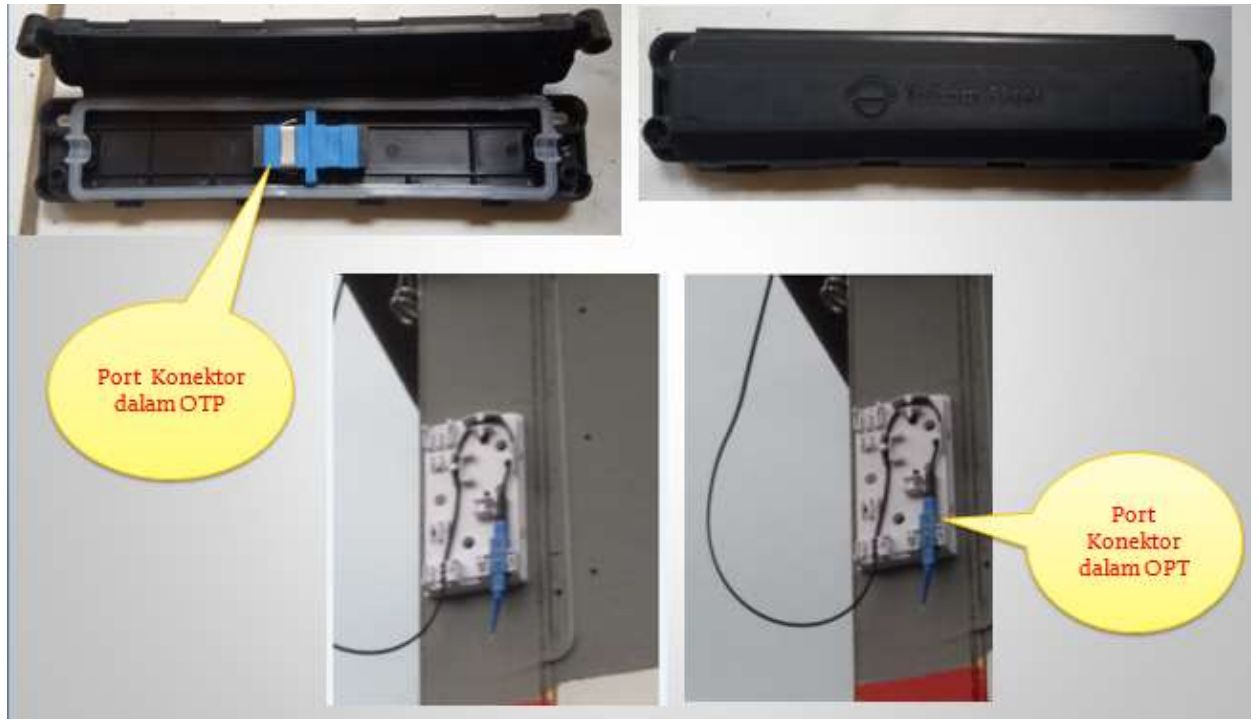

Gambar 11. Contoh Phisik dari Perangkat OTP

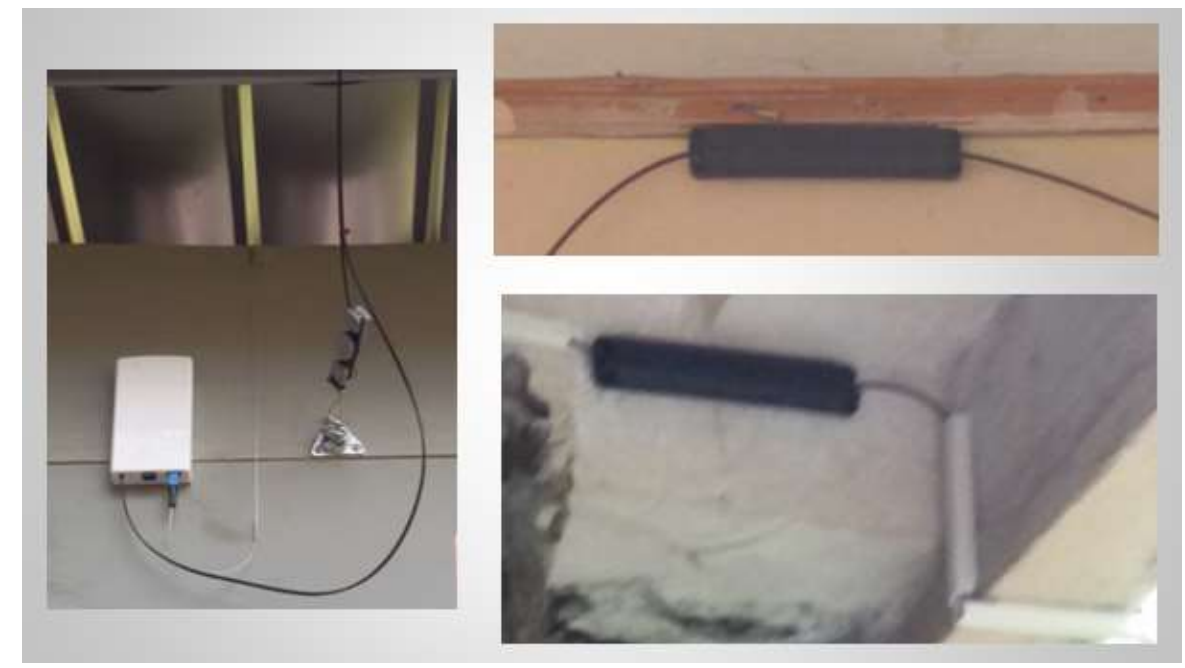

Gambar 12. Contoh Pemasangan Perangkat OTP di Rumah Pelanggan FTTH

Beberapa hal yang perlu dipertimbangkan dalam pemasangan perangkat OTP [3][4] diantaranya:

a. Posisi pemasangan OTP harus terlindung dari gangguan phisik maupun cuaca seperti panas dan hujan.

b. Posisi pemasangan OTP sedapat mungkin dekat dengan tempat/jalur untuk masuknya kabel indoor masuk ke dalam rumah.

c. Ketinggian pemasangan OTP minimal 2,5 meter atau disesuaikan dengan kondisi lapangan dan Pelanggan.

d. OTP harus terpasang kuat pada tempatnya baik di dinding tembok atau kayu.

e. Memperhatikan nilai estetika dan memberikan kemudahan petugas dalam bekerja.

f. Lubang atau jalur masuk/keluar kabel dari OTP harus tertutup rapat dengan menggunakan penutup celah/lubang untuk menghindari kelembaban, debu, binatang kecil, maupun masuknya 
serangga. Penutupan lubang kabel harus dapat juga berfungsi sebagai penahan kabel drop maupun indoor yang masuk/keluar di OTP.

g. Prosedur atau cara instalasi perangkat OTP dan perkabelan dalam rumah pelanggan FTTH [7] dapat dilihat pada gambar berikut ini.

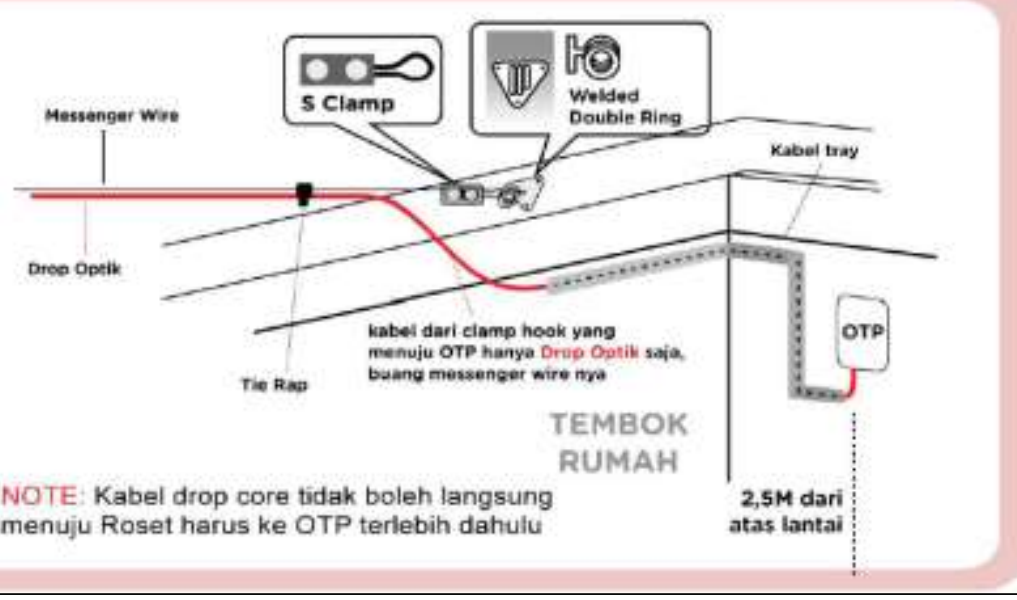

Gambar 13. Contoh Pemasangan Perangkat OTP di Dinding Rumah Pelanggan FTTH

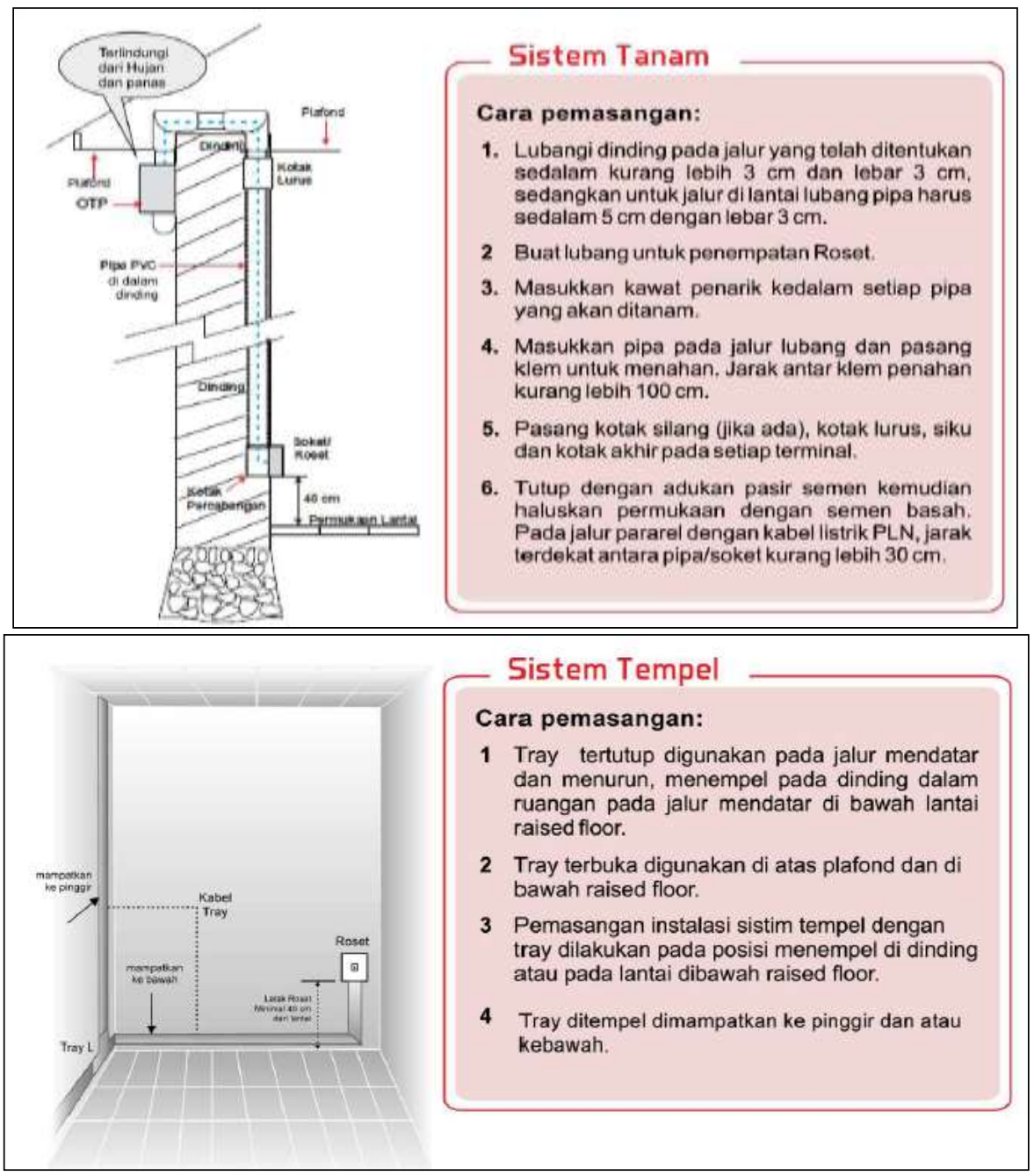

Gambar 14. Contoh Penarikan Kabel dari OTP ke Dalam Rumah Pelanggan FTTH 


\section{KESIMPULAN}

a. Dipasangnya perangkat OTP pada jaringan pelanggan FTTH akan mempercepat perbaikan/penyelesaian gangguan pelanggan dan menghemat pemakaian/penggunaan kabel drop.

b. Persyaratan pemasangan perangkat OTP diantaranya harus terlindung dari gangguan phisik dan cuaca, dekat dengan jalur/tempat untuk masuknya kabel indoor, ketinggian OTP 2,5 meter dari permukaan tanah dan memperhatikan nilai estetika.

\section{Daftar Pustaka:}

[1] Telkom. 2015. Laporan Akhir Hasil Uji Petik FTTH 2015, Bandung

[2] Telkom. 2015. Pedoman Desain Distribusi Jaringan Fiber Optik Terpadu (Desain i-ODN) Versi 1.0, Bandung

[3] Telkom. 2015. Pedoman Instalasi Perangkat Distribusi Jaringan Fiber Optik Terpadu (i-ODN) Versi 1.0, Bandung

[4] Telkom. 2015. Pedoman Instalasi Kabel Distribusi Jaringan Fiber Optik Terpadu (i-ODN) Versi 1.0, Bandung

[5] Hamzah, Andi, Nasri. 2015. Pekerjaan IKR pada Jaringan Fiber To The Home (FTTH) at http://osptelkom.blogspot.co.id/2014/01/pekerjaan-ikr-pada-jaringan-fiber-to_4.html

[6] Fujikura-Telkom Akses. 2014. Dokumen Guide Book For Fiber To The Home Connect (FTTH-Premises) Versi 1.0, Jakarta

[7] Telkom Akses. 2015. Dokumen Quick Guide Standar Instalasi Provisioning Typw-1 (PT-1), Bandung

[8] Manggolo, Inu. 2011. Optimalisasi Perencanaan Jaringan Akses Serat Optik Fiber To The Home Menggunakan Algoritma Genetika, Jakarta; Program Magister Teknik Elektro Universitas Mercu Buana 